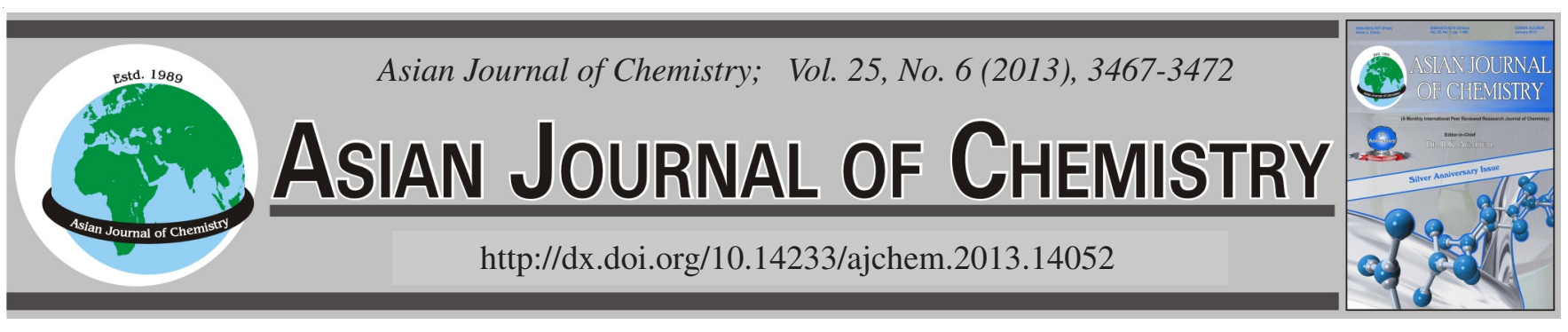

\title{
Differential Pulse Polarographic Determination of Atorvastatin in Pharmaceutical Dosage Forms Using Dropping Mercury Electrode
}

\author{
Abdul Aziz Ramadan ${ }^{*}$, Hasna Mandil and BaraA Hafez
}

Department of Chemistry, Faculty of Sciences, Aleppo University, Aleppo, Syria

*Corresponding author: Fax: +963 21 2633136; E-mail: dramadan@scs-net.org; mandil@ scs-net.org

\begin{abstract}
New, simple and rapid differential pulse polarographic analysis by using dropping mercury electrode with negative amplitude pulse was developed for determination of atorvastatin in pure and pharmaceutical dosage forms in borax buffer at $\mathrm{pH}$ 7.5. One reduction peak was observed in the range -1310 to $-1340 \mathrm{mV}\left(\mathrm{E}_{\mathrm{p}}\right)$. The peak current $\mathrm{I}_{\mathrm{p}}$ is linear over the ranges $2-60 \mu \mathrm{mol} \mathrm{L} \mathrm{L}^{-1}$. The differential pulse polarographic analysis has been used successfully for the determination of atorvastatin in pure form and in pharmaceutical formulations. The relative standard deviation did not exceed $3.8 \%$ for the concentrations of atorvastatin $2.00 \mu \mathrm{mol} \mathrm{L}^{-1}\left(1.117 \mu \mathrm{g} \mathrm{mL} \mathrm{mL}^{-1}\right)$. Regression analysis showed a good correlation coefficient $\left(\mathrm{R}^{2}=0.9994\right)$ between $\mathrm{I}_{\mathrm{p}}$ and concentration over the range of 1.117 to $33.52 \mu \mathrm{g} \mathrm{mL} \mathrm{m}^{-1}$. The limit of detection and the limit of quantification were $0.129 \mu \mathrm{g} \mathrm{mL}^{-1}$ and $0.390 \mu \mathrm{g} \mathrm{mL} \mathrm{m}^{-1}$, respectively. The proposed method was successfully applied to the analysis of atorvastatin in pure and pharmaceutical dosage forms with average recovery of 97.2 to $104.2 \%$. The results obtained agree well with the contents stated on the labels.
\end{abstract}

Key Words: Differential pulse polarographic analysis, Atorvastatin, Pharmaceuticals.

\section{INTRODUCTION}

Atorvastatin calcium ${ }^{1,2}$ is a calcium $(\mathrm{bR}, \mathrm{dR})-2-(\mathrm{r}-$ fluorophenyl)-b,d-dihydroxy-5-isopropyl-3-phenyl-4(phenylcarbamoyl)pyrrole-1-hepatanoicacid (1:2) trihydrate. The empirical formula of atorvastatin calcium trihydrate is $\mathrm{C}_{66} \mathrm{H}_{68} \mathrm{~N}_{4} \mathrm{O}_{10} \mathrm{CaF}_{2} \cdot 3 \mathrm{H}_{2} \mathrm{O}$ or $\left(\mathrm{C}_{33} \mathrm{H}_{34} \mathrm{~N}_{2} \mathrm{O}_{5} \mathrm{~F}\right)_{2} \mathrm{Ca} \cdot 3 \mathrm{H}_{2} \mathrm{O}$, mol.mass $1209.4 \mathrm{~g}$; where the empirical formula of atorvastatin is $\mathrm{C}_{33} \mathrm{H}_{35} \mathrm{FN}_{2} \mathrm{O}_{5}$, mol. mass $558.64 \mathrm{~g}$ (Fig. 1). Atorvastatin calcium is a white to off-white crystalline powder that is insoluble in aqueous solutions of $\mathrm{pH} 4$ and below. Atorvastatin calcium is very slightly soluble in distilled water, $\mathrm{pH} 7.4$ phosphate buffer and acetonitrile; slightly soluble in ethanol and freely soluble in methanol. Atorvastatin is a member of the drug class known as statins, used for lowering blood cholesterol. It also stabilizes plaque and prevents strokes through antiinflammatory and other mechanisms. It is alipid regulating drug with actions on plasma lipids similar to those of simvastatin ${ }^{2-4}$. Several studies have been reported for the determination of atorvastatin in pure form, in pharmaceutical formations and in biological fluids including spectrophotometric methods $\mathrm{s}^{2,5-8}$, electrophoresis $^{9,10}$, chromatographic methods with different detectors ${ }^{11-16}$ and electrochemical, polarographic and voltammetric methods ${ }^{17-21}$.

The electrochemical behaviour of atorvastatin calcium at glassy carbon and boron-doped diamond electrodes has been studied using voltammetric techniques. The possible mechanism of oxidation was discussed with model compounds. The dependence of the peak current and potentials on $\mathrm{pH}$, concentration, scan rate and nature of the buffer were investigated for both electrodes. The oxidation of atorvastatin was irreversible and exhibited a diffusion controlled fashion on the diamond electrode. A linear response was obtained within the range of $9.65 \times 10^{-7}-3.86 \times 10^{-5} \mathrm{M}$ in $0.1 \mathrm{M} \mathrm{H}_{2} \mathrm{SO}_{4}$ solution for both electrodes. The detection limits of a standard solution are estimated to be $2.11 \times 10^{-7} \mathrm{M}$ with differential pulse voltammetry (DPV) and $2.05 \times 10^{-7} \mathrm{M}$ with square wave voltammetry (SWV) for glassy carbon electrode and $2.27 \times$ $10^{-7} \mathrm{M}$ with differential pulse voltammetry and $1.31 \times 10^{-7} \mathrm{M}$ with square wave voltammetry for diamond electrodes in 0.1 $\mathrm{M} \mathrm{H}_{2} \mathrm{SO}_{4}$ solution. The repeatability of the methods was found good for both electrodes. The methods were fully validated and successfully applied to the high-throughput determination of the drug in tablets, human serum and human urine with good recoveries ${ }^{19}$.

The electrochemical behaviour of atorvastatin and amlodipine at a glassy carbon electrode has been studied using different voltammetric techniques. First derivative of the ratio voltammetric methods for determination of amlodipine and atorvastatin in tablets in the presence of the other compound has been described. This technique depends on the measuring 
of first derivative of the ratio voltammograms of each concentration as a function of the increased concentrations. Differential pulse and square wave voltammetric methods depend on first derivative of the ratio voltammetry by measurements of the selected potentials for amlodipine and atorvastatin. The linear response was within the range of $4 \times 10^{-6}-1 \times 10^{-4} \mathrm{M}$ for amlodipine and $2 \times 10^{-6}-1 \times 10^{-4} \mathrm{M}$ for atorvastatin. The proposed methods have been extensively validated ${ }^{20}$.

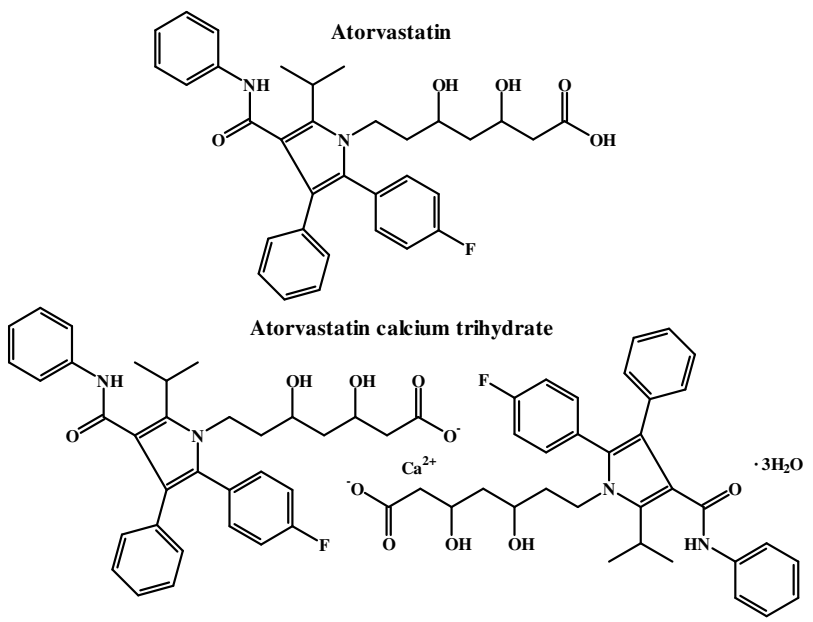

Fig. 1. Chemical structure of atorvastatin and atorvastatin calcium trihydrate

Electrochemical behaviour of atorvastatin and optimum conditions to its quantitative determination were investigated using voltammetric methods. Some electrochemical parameters such as diffusion coefficient, surface coverage of adsorbed molecules, electron transfer coefficient, standard rate constant and number of electrons were calculated using the results of cyclic voltammetry. A tentative mechanism for the oxidation for atorvastatin has been suggested. The oxidation signal of atorvastatin molecule was used to develop fully validated, new, rapid, selective and simple square-wave anodic adsorptive stripping voltammetric (AdsSWV) and differential pulse anodic stripping voltammetric (AdsDPV) methods to direct determination of atorvastatin in pharmaceutical dosage forms and biological samples. For the AdsDPV and AdsSWV techniques, linear working ranges were found to be $1.0 \times 10^{-7}-5.0 \times 10^{-6}$ and $3.0 \times 10^{-7}-5.0 \times 10^{-6} \mathrm{molL}^{-1}$, respectively. The detection limits obtained from AdsDPV and AdsSWV were calculated to be $6.55 \times 10^{-8}$ and $1.53 \times 10^{-7}$ mol L ${ }^{-1}$, respectively. The methods were successfully applied to assay the drug in tablets, human blood serum and human urine $^{21}$

In the present work, novel differential pulse polarographic method on dropping mercury electrode with negative amplitude was applied for determination of atorvastatin in pure and in pharmaceutical dosage forms using borax buffer at $\mathrm{pH}$ 7.5.

\section{EXPERIMENTAL}

A Metrohm 746 VA processor, A Metrohm 747 VA stand with a multi-mode electrode (MME) comprising a dropping mercury electrode, static mercury drop electrode and hanging mercury drop electrode as a working electrode, an auxiliary platinum electrode and a reference electrode, double junction type, $(\mathrm{Ag} / \mathrm{AgCl})$ saturated with a $3.0 \mathrm{M} \mathrm{KCl}$ solution and the three-electrode cell were used. All measurements were done at room temperature $25 \pm 5^{\circ} \mathrm{C}$. Pure nitrogen gas $(99.999 \%)$ was used for de-oxygenation. $\mathrm{pH}$ meter from radio meter company model ion check was used for the studying and monitoring the $\mathrm{pH}$ effects. The diluter pipette model DIP-1 (Shimadzu), having $100 \mathrm{~mL}$ sample syringe and five continuously adjustable pipettes covering a volume range from 20 to $5000 \mu \mathrm{L}$ (model PIPTMAN P, GILSON), were used for preparation of the experimental solutions. A ultrasonic processor model POWERSONIC 405 was used to sonicate the sample solutions. Electronic balance (Sartorius-2474; 0.01 $\mathrm{mg}$ ) was used for weighing the samples.

Working reference standard of atorvastatin calcium trihydrate was supplied by ind-swift (India), its purity as atorvastatin was $92.0 \%$. Concentrated phosphoric acids, di-sodium tetraborate decahydrate (borax) $\mathrm{Na}_{2} \mathrm{~B}_{4} \mathrm{O}_{7} \cdot 10 \mathrm{H}_{2} \mathrm{O}$, mol mass $381.37 \mathrm{~g}$, were of extra pure purchased from Merck. Ultrapure mercury from Metrohm company was used. Supporting electrolytes (buffer) were prepared by dissolving $7.15 \mathrm{~g}$ borax in $240 \mathrm{~mL}$ then adding $6.5 \mathrm{~mL}$ from $\mathrm{H}_{3} \mathrm{PO}_{4}$ $(1.0 \mathrm{M})$ and completing to $250 \mathrm{~mL}$ volumetric flask by adding double distilled deionized water until reaching to the desired $\mathrm{pH}=7.5$. A stock standard solutions of atorvastatin calcium trihydrate (a) $1 \times 10^{-3} \mathrm{~mol} \mathrm{~L}^{-1}$ and (b) $1 \times 10^{-5} \mathrm{~mol} \mathrm{~L}^{-1}$ of atorvastatin was prepared from atorvastatin calcium trihydrate in $50 \mathrm{~mL}$ mixture methanol: water $(9: 1, \mathrm{v} / \mathrm{v})$. These stock solutions were further diluted to obtain working solutions daily just before use in the ranges of atorvastatin: $2,4,8,16$, 24, 32, 40, 50, 60 and $70 \mu \mathrm{mol} \mathrm{L}-1$ (1.117, 2.234, 4.468, 8.936,

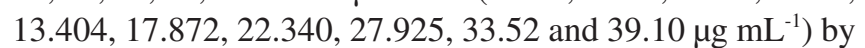
dilution of the volumes: $0.5,1$ from stock standard solutions (b), 0.2, 0.4, 0.6, 0.8, 1, 1.25, 1.5 and $1.75 \mathrm{~mL}$ from stock standard solutions(a) to $25 \mathrm{~mL}$ with supporting electrolyte. All solutions and reagents were prepared with double-distilled deionized water and analytical grade chemicals.

Sample preparation: A commercial formulations (as tablet) were used for the analysis of atorvastatin by using differential pulse polarographic analysis. The pharmaceutical formulations were subjected to the analytical procedures:

(1) Atorvex tablets, Asia pharmaceutical industries, Aleppo-Syria, each tablet contains: 10,20 and $40 \mathrm{mg}$ of atorvastatin.

(2) Atorvatin tablets, Alpha, Aleppo pharmaceutical industries, Aleppo-Syria, each tablet contains: 10, 20 and 40 $\mathrm{mg}$ of atorvastatin.

(3) Lipito-med tablets, Medico labs., Homs-Syria, each tablet contains: 10,20 and $40 \mathrm{mg}$ of atorvastatin.

(4) Lipostatin tablets, Ibn Al-Haytham Pharma Industries Co., Aleppo-Syria, each tablet contains: 10, 20 and $40 \mathrm{mg}$ of atorvastatin.

(5) Atoraz tablets, Razi pharmaceutical industries, AleppoSyria, each tablet contains: 10, 20 and $40 \mathrm{mg}$ of atorvastatin. Stock solutions of pharmaceutical formulations: Three tablets of each studied pharmaceutical formulations were weighted accurately, crushed to a fine powder and mixed well. Equivalent tenth the weight of one tablet, was solved in $40 \mathrm{~mL}$ methanol : water $(9: 1)$ by using ultrasonic, filtered over a 50 $\mathrm{mL}$ flask and diluting to $50 \mathrm{~mL}$ with methanol : water, which 
content as the follows : 20,40 and $80 \mathrm{mg} \mathrm{mL}^{-1}$ for all studied pharmaceutical formulations content 10,20 and $40 \mathrm{mg} / \mathrm{tab}$, respectively.

Working solutions of pharmaceuticals: These solutions were prepared daily by diluting 5, 2.5 and $1.25 \mathrm{~mL}$ from stock solutions of pharmaceutical formulations, respectively, then diluting to $25 \mathrm{~mL}$ with supporting electrolyte (each solution contents $4 \mu \mathrm{g} \mathrm{mL} \mathrm{L}^{-1}$ of atorvastatin).

Working standard addition solutions of pharmaceuticals: These solutions were prepared as the follows: same mentioned volumes of stock solutions of pharmaceuticals with $0.2,0.4$, 0.6 and $0.8 \mathrm{~mL}$ from stock solution (a) of atorvastatin and diluting to $25 \mathrm{~mL}$ with supporting electrolytes; these solutions content $4.000 \mu \mathrm{g} \mathrm{mL}^{-1}$ of atorvastatin (from different pharmaceuticals) plus $4.469,8.938,13.407$ and $17.876 \mu \mathrm{g} \mathrm{mL}^{-1}$ of atorvastatin, respectively.

Procedure: A $25 \mathrm{~mL}$ volume of a solution containing an appropriate concentration of atorvastatin with supporting electrolytes (buffer), or working solutions of pharmaceuticals at $\mathrm{pH} 7.5$ and temperature at $25 \pm 5^{\circ} \mathrm{C}$ was transferred into the three-electrode cell. The potential was scanned from -600 to $-1500 \mathrm{mV}$ with the auto-scan facility.

\section{RESULTS AND DISCUSSION}

Polarographic behaviour: The polarograms in the optimal conditions (supporting electrolytes, $\mathrm{pH}$, scan rate, initial potential and final potential, etc.) using differential pulse polarographic analysis at dropping mercury electrode were studied. The peak potential was measured at -1310 to -1340 $\mathrm{mV}$.

Effect of pH: First, the influence of $\mathrm{pH}$ on $\mathrm{I}_{\mathrm{p}}$ was studied. The maximum peak $\left(\mathrm{I}_{\mathrm{p}}\right)$ occurs at approximately $\mathrm{pH} 7.5$ (Fig. 2). The effect of $\mathrm{pH}$ on peak potential $\left(\mathrm{E}_{\mathrm{p}}\right)$ shows the following: when $\mathrm{pH}$ value decreasing between 9 to $6.5, \mathrm{E}_{\mathrm{p}}$ remains almost constant, but decreases $\mathrm{pH}$ value after that $\mathrm{E}_{\mathrm{p}}$ increases sharply to negative value (Fig. 3).

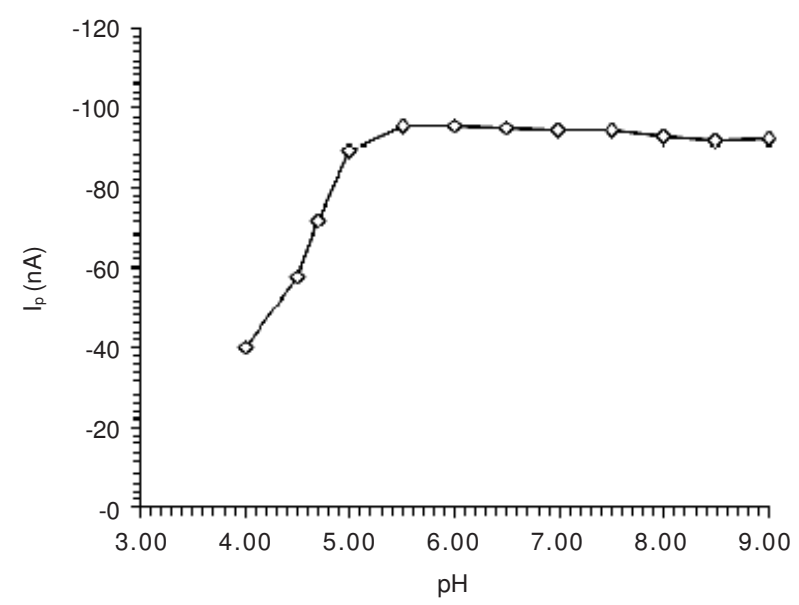

Fig. 2. Effect of $\mathrm{pH}$ solution on $\mathrm{I}_{\mathrm{p}}$ of AT using DPPA at DME, $\left(\mathrm{C}_{\mathrm{AT}}=20.5\right.$ $\left.\mu \mathrm{g} \mathrm{mL} L^{-1}\right)$

Effect of supporting electrolytes (buffer): The effect of supporting electrolytes (buffer) on the $\mathrm{I}_{\mathrm{p}}$ was studied. It was found that, the borax was the better buffer at concentration $0.075 \mathrm{~mol} \mathrm{~L}^{-1}$ (Fig. 4).

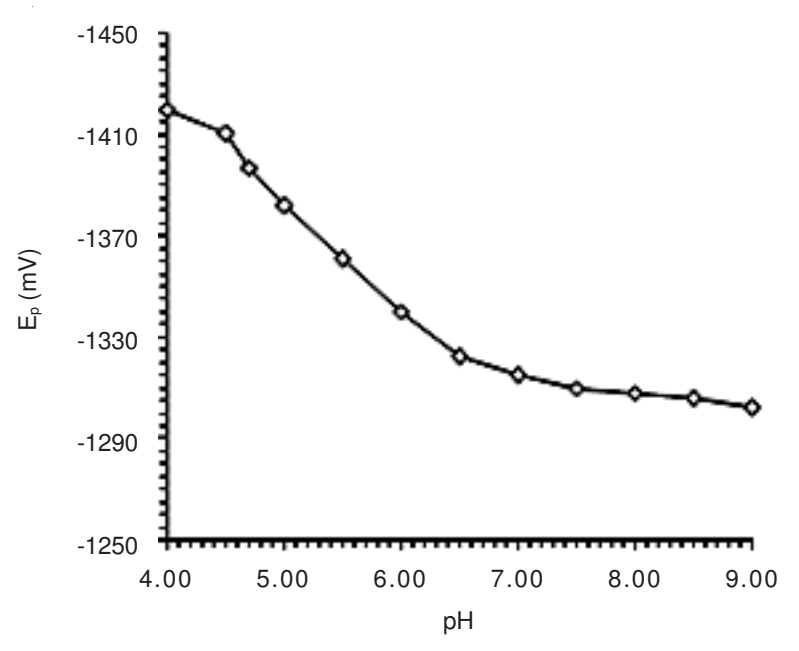

Fig. 3. Effect of $\mathrm{pH}$ solution on $\mathrm{E}_{\mathrm{p}}$ of atorvastatin using DPPA at DME, $\left(\mathrm{C}_{\mathrm{AT}}=20.5 \mu \mathrm{g} \mathrm{mL} \mathrm{m}^{-1}\right)$

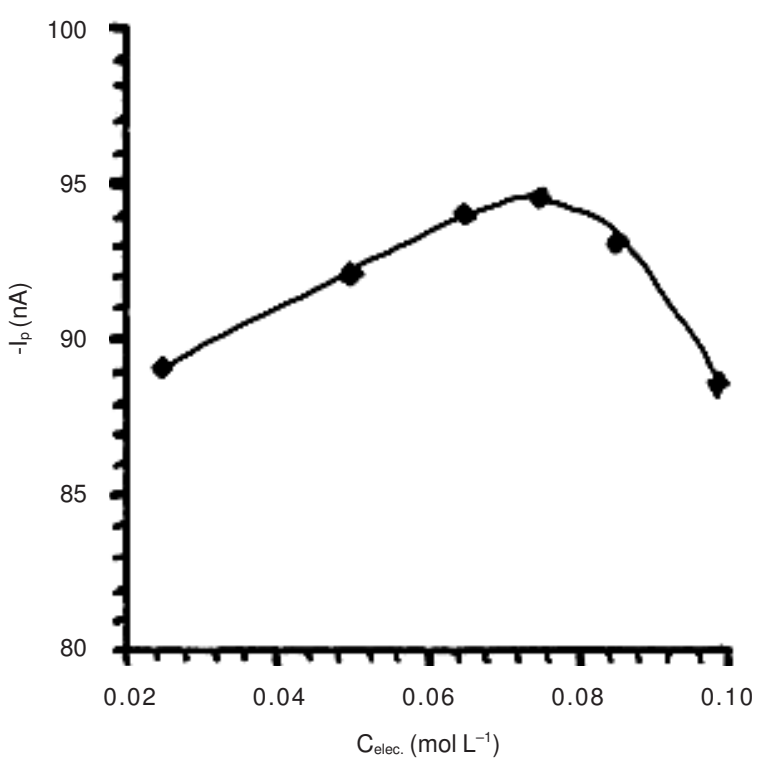

Fig. 4. Effect of electrolyte concentration on $\mathrm{I}_{\mathrm{p}}$, of atorvastatin using DPPA at DME, $\left(\mathrm{C}_{\mathrm{AT}}=20.5 \mu \mathrm{g} \mathrm{mL} \mathrm{m}^{-1}, \mathrm{pH}=7.5\right)$

Effect of negative pulse amplitude: The effect of negative pulse amplitude between 0 to $100 \mathrm{mV}$ on $\mathrm{I}_{\mathrm{p}}$ showed that, the value $90 \mathrm{mV}$ was better than another's.

Effect of scan rate: The different values of scan rate (3.3, $6.6,10,13.3,16.6$ and $20 \mathrm{mV} / \mathrm{s}$ ) were studied. It was found that, the value scan rate $10 \mathrm{mV} / \mathrm{s}$ was the better.

Effect of initial and final potential: The effect of initial and final potential on the $I_{p}$ was studied. It was found that better initial potential was $-600 \mathrm{mV}$ and better final potential was $-1500 \mathrm{mV}$.

Effect of temperature and time: The effect of temperature and time on the electrochemical reaction of atorvastatin was studied at different values $\left(15-35^{\circ} \mathrm{C}, 5-60 \mathrm{~min}\right)$ by continuous monitoring of the $I_{p}$. It was found that, the value of $I_{p}$ was not affected by temperature between 20 to 30 (the temperature at $25 \pm 5^{\circ} \mathrm{C}$ was used). The effect of waiting time was determined at laboratory ambient temperature $\left(25 \pm 5^{\circ} \mathrm{C}\right)$. It was found that, the value of $\mathrm{I}_{\mathrm{p}}$ was not affected by time between 5 to $60 \mathrm{~min}$. 
The optimum parameters established for determination of atorvastatin using differential pulse polarographic analysis on dropping mercury electrode showed in Table-1.

\begin{tabular}{|c|c|}
\hline $\begin{array}{r}\text { TA } \\
\text { THE OPTIMUM PARAM } \\
\text { DETERMINATION OF ATORV } \\
\text { PULSE POLAROGRAPHI } \\
\text { MERCURY ELECTRODE V } \\
\text { IN BORAX B }\end{array}$ & $\begin{array}{l}\text { BLE-1 } \\
\text { ETERS ESTABLISHED FOR } \\
\text { ASTATIN USING DIFFERENTIAL } \\
\text { ANALYSIS ON DROPPING } \\
\text { ITH NEGATIVE AMPLITUDE } \\
\text { JFFER AT pH } 7.5\end{array}$ \\
\hline Parameters & Operating modes \\
\hline Indicator electrode & Dropping mercury electrode \\
\hline Supporting electrolytes (buffer) & Borax, $0.075 \mathrm{~mol} \mathrm{~L}^{-1}$ \\
\hline $\mathrm{pH}$ & 7.5 \\
\hline Solvent for atorvastatin & Methanol : water $(9: 1, \mathrm{v} / \mathrm{v})$ \\
\hline Value of pulse amplitude & $-90 \mathrm{mV}$ \\
\hline Purge gas & Pure $\mathrm{N}_{2}$ \\
\hline Purge time & $200 \mathrm{sec}$. \\
\hline Initial potential & $-600 \mathrm{mV}$ \\
\hline Final potential & $-1500 \mathrm{mV}$ \\
\hline Pulse duration & $20 \mathrm{~ms}$ \\
\hline Scan rate & $10 \mathrm{mV} / \mathrm{s}$ \\
\hline Age drop of mercury & $0.6 \mathrm{sec}$ \\
\hline Temperature of solution & $25^{\circ} \pm 5^{\circ} \mathrm{C}$ \\
\hline Peak Potential, mV & -1310 to $-1340 \mathrm{mV}$ \\
\hline $\operatorname{LOD}(3.3 \mathrm{SD})$ & $0.129 \mu \mathrm{g} \mathrm{mL}^{-1}$ \\
\hline LOQ (10SD) & $0.390 \mu \mathrm{g} \mathrm{mL}^{-1}$ \\
\hline Linearity range of concentration & $\begin{array}{l}1.117 \mu \mathrm{g} \mathrm{mL}^{-1}(2.00 \mu \mathrm{M}) \text { to } 33.52 \\
\mu \mathrm{g} \mathrm{mL} L^{-1}(60.00 \mu \mathrm{M})\end{array}$ \\
\hline Regression equation: & $* y=4.576 x+0.283$ \\
\hline Slope & 4.576 \\
\hline Intercept & 0.283 \\
\hline Correlation coefficient $\left(\mathrm{R}^{2}\right)$ & 0.9994 \\
\hline RSD & $3.8 \%$ \\
\hline
\end{tabular}

Calibration curves: Calibration curves for the determination of atorvastatin using differential pulse polarographic analysis on dropping mercury electrode with negative amplitude in borax buffer at $\mathrm{pH} 7.5$ were applied. The peak current $\left(\mathrm{I}_{\mathrm{p}}\right)$ was proportional to the concentration of atorvastatin over the ranges $2-60 \mu \mathrm{M}\left(1.117-33.52 \mu \mathrm{g} \mathrm{mL}^{-1}\right)$, the regression equation and correlation coefficient $\left(\mathrm{R}^{2}\right)$ were as the follows: $\mathrm{y}=4.576 \mathrm{x}+0.283, \mathrm{R}^{2}=0.9994 ; \mathrm{y}: \mathrm{I}_{\mathrm{p}}, \mathrm{nA}$ and $\mathrm{x}: \mathrm{C}_{\mathrm{AT}}, \mu \mathrm{g} \mathrm{mL}^{-1}$ (Fig. 5).

Analytical results: Determination of atorvastatin using differential pulse polarographic analysis on dropping mercury electrode with negative amplitude in borax buffer at $\mathrm{pH} 7.5$ using analytical curves, $\mathrm{I}_{\mathrm{p}}=\mathrm{f}(\mathrm{CAT})$, showed that the accuracy was ready over the ranges of atorvastatin concentration between 1.117-33.52 $\mathrm{mg} \mathrm{mL}^{-1}$ and relative standard deviation (RSD) not more than $3.8 \%$, see Table-2. Limit of detection (LOD) and limit of quantitation (LOQ) for the determination of atorvastatin by this method were as the follows : 0.136 and $0.413 \mathrm{mg} \mathrm{mL}^{-1}$, respectively.

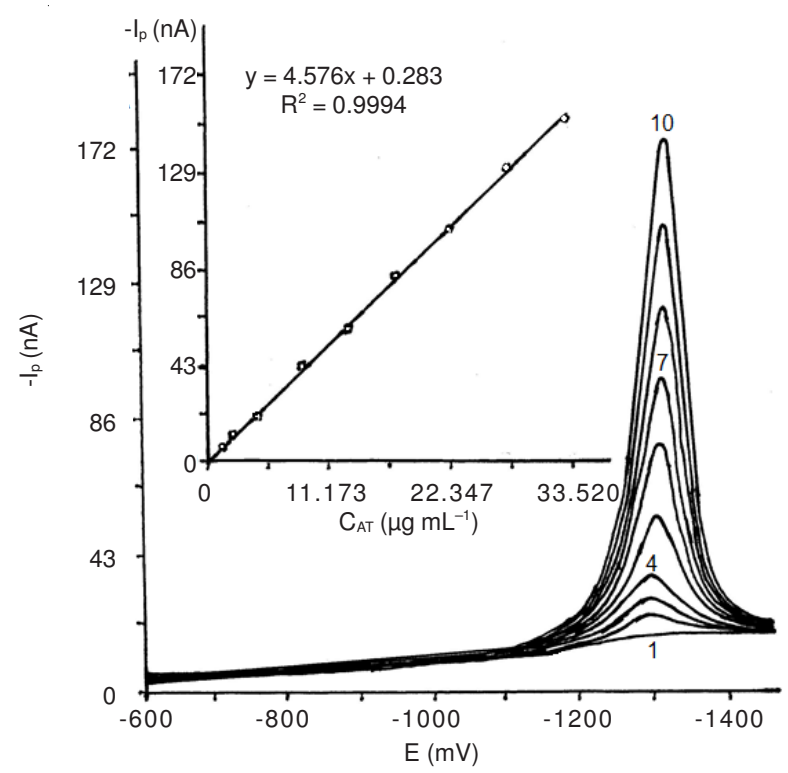

Fig. 5. Polarogramsin the optimum conditions using DPPA at DME of atorvastatin at concentrations: 1) 0 ; 2) 1.117 ; 3) 2.234; 4) 4.468; 5) 8.936 ; 6) 13.404 ; 7) 17.872 ; 8) 22.340 ; 9) 27.925; 10) $33.52 \mathrm{mg}$ $\mathrm{mL}^{-1}$ and calibration curve $(\mathrm{pH} 7.5)$

Applications: Many applications for the determination of atorvastatin in some Syrian pharmaceutical preparations using differential pulse polarographic analysis on dropping mercury electrode with negative amplitude in borax buffer at pH 7.5 were proposed. Standard addition curves for determination of atorvastatin in different Syrian pharmaceutical preparations (atorvex, atorvatin, lipito-med, lipostatin and atoraz) were used. The standard addition curve of atorvex (10 mg/tab.) was showed in Fig. 6. Regression equations and correlation coefficients were included in Table-3. Standard addition curves for determination of atorvastatin in different Syrian pharmaceutical preparations were used. The amount

TABLE-2

DETERMINATION OF ATORVASTATIN USING DIFFERENTIAL PULSE POLAROGRAPHIC ANALYSIS ON DROPPING MERCURY ELECTRODE WITH NEGATIVE AMPLITUDE IN BORAX BUFFER AT pH 7.5

\begin{tabular}{|c|c|c|c|c|c|}
\hline $\begin{array}{l}\mathrm{x}_{\mathrm{i}}, \mu \mathrm{g} \mathrm{mL^{-1 }} \\
\text { (Taken) }\end{array}$ & $\begin{array}{c}\overline{\mathrm{X}} *, \mu \mathrm{g} \mathrm{mL} \mathrm{L}^{-1} \\
\text { (Found) }\end{array}$ & $\mathrm{SD}, \mu \mathrm{g} \mathrm{mL}^{-1}$ & $\frac{\mathrm{SD}}{\sqrt{\mathrm{n}}}, \mu \mathrm{g} \mathrm{mL}^{-1}$ & $\overline{\mathrm{x}} \pm \frac{\mathrm{t} . \mathrm{SD}}{\sqrt{\mathrm{n}}}, \mu \mathrm{g} \mathrm{mL} \mathrm{L}^{-1}$ & $\operatorname{RSD}(\%)$ \\
\hline 1.028 & 1.02 & 0.039 & 0.017 & $1.02 \pm 0.048$ & 3.8 \\
\hline 4.110 & 4.12 & 0.14 & 0.062 & $4.12 \pm 0.174$ & 3.5 \\
\hline 8.221 & 8.25 & 0.27 & 0.121 & $8.25 \pm 0.335$ & 3.3 \\
\hline 12.332 & 12.32 & 0.38 & 0.170 & $12.32 \pm 0.472$ & 3.1 \\
\hline 20.553 & 20.55 & 0.62 & 0.277 & $23.67 \pm 0.770$ & 3.0 \\
\hline 25.69 & 25.70 & 0.80 & 0.358 & $25.70 \pm 0.993$ & 3.1 \\
\hline 30.83 & 30.78 & 0.98 & 0.438 & $30.78 \pm 1.217$ & 3.2 \\
\hline
\end{tabular}




\begin{tabular}{|c|c|c|c|c|}
\hline \multicolumn{5}{|c|}{$\begin{array}{c}\text { TABLE-3 } \\
\text { REGRESSION EQUATIONS AND CORRELATION COEFFICIENTS FOR DETERMINATION OF ATORVASTATIN IN SYRIAN } \\
\text { PHARMACEUTICAL PREPARATIONS USING DIFFERENTIAL PULSE POLAROGRAPHIC ANALYSIS ON DROPPING } \\
\text { MERCURY ELECTRODE WITH NEGATIVE AMPLITUDE IN BORAX BUFFER AT pH 7.5 }\end{array}$} \\
\hline \multirow{2}{*}{$\begin{array}{c}\text { Pharmaceutical } \\
\text { preparations }\end{array}$} & \multirow{2}{*}{$\begin{array}{c}\text { Atorvastatin } \\
\text { in tab (mg) }\end{array}$} & \multicolumn{3}{|c|}{ Operating modes } \\
\hline & & Regression equations $^{*}$ & Correlation coefficients & Amount of atorvastatin $(\mathrm{m})(\mathrm{mg} / \mathrm{tab})$ \\
\hline Atorvex, ctd. tab. Asia & 10 & $y=4.575 x+18.70$ & $\mathrm{R}^{2}=0.9988$ & $\mathrm{~m}_{\text {AT/tab. }}=2.5 \mathrm{~m}^{\prime}=10.22$ \\
\hline pharmaceutical industries & 20 & $y=4.576 x+19.07$ & $R^{2}=0.9989$ & $\mathrm{~m}_{\mathrm{AT} / \mathrm{ab} .}=5 \mathrm{~m}^{\prime}=20.84$ \\
\hline Aleppo-SYRIA & 40 & $y=4.575 x+18.67$ & $\mathrm{R}^{2}=0.9991$ & $\mathrm{~m}_{\text {AT/tab.. }}=10 \mathrm{~m}^{\prime}=40.80$ \\
\hline Atorvatin, Ctd. tab. Alpha & 10 & $y=4.578 x+18.10$ & $\mathrm{R}^{2}=0.9981$ & $\mathrm{~m}_{\text {AT/tab. }}=2.5 \mathrm{~m}^{\prime}=9.88$ \\
\hline Aleppo Pharmaceutical & 20 & $y=4.572 x+18.42$ & $\mathrm{R}^{2}=0.9987$ & $\mathrm{~m}_{\mathrm{AT} \text { /ab. }}=5 \mathrm{~m}^{\prime}=20.14$ \\
\hline Industries - SYRIA & 40 & $y=4.579 x+18.30$ & $\mathrm{R}^{2}=0.9989$ & $\mathrm{~m}_{\mathrm{AT} / \mathrm{ab} .}=10 \mathrm{~m}^{\prime}=40.0$ \\
\hline Lipito-med, Ctd.tab. & 10 & $y=4.574 x+18.22$ & $\mathrm{R}^{2}=0.9985$ & $\mathrm{~m}_{\text {AT/tab. }}=2.5 \mathrm{~m}^{\prime}=9.96$ \\
\hline Medico Labs. & 20 & $y=4.577 x+18.86$ & $R^{2}=0.9987$ & $\mathrm{~m}_{\mathrm{AT} / \mathrm{ab} .}=5 \mathrm{~m}^{\prime}=20.60$ \\
\hline Homs-SYRIA & 40 & $y=4.573 x+18.38$ & $R^{2}=0.9990$ & $\mathrm{~m}_{\mathrm{AT} \text { tab. }}=10 \mathrm{~m}^{\prime}=40.20$ \\
\hline Liostatin, ctd. tab. Ibn Ai & 10 & $y=4.576 x+18.87$ & $R^{2}=0.9984$ & $\mathrm{~m}_{\mathrm{AT} / \mathrm{ab}}=2.5 \mathrm{~m}^{\prime}=10.31$ \\
\hline Haytham, Pharma Industries & 20 & $y=4.574 x+18.61$ & $R^{2}=0.9986$ & $\mathrm{~m}_{\mathrm{AT} / \mathrm{ab} .}=5 \mathrm{~m}^{\prime}=20.34$ \\
\hline Co., Aleppo-SYRIA & 40 & $y=4.577 x+18.51$ & $\mathrm{R}^{2}=0.9991$ & $\mathrm{~m}_{\mathrm{AT \text {tab }}}=10 \mathrm{~m}^{\prime}=40.44$ \\
\hline Atoraz, Ctd.tab. Razi & 10 & $y=4.575 x+17.79$ & $\mathrm{R}^{2}=0.9980$ & $\mathrm{~m}_{\text {AT/tab. }}=2.5 \mathrm{~m}^{\prime}=9.72$ \\
\hline pharmaceutical industries & 20 & $y=4.577 x+18.23$ & $\mathrm{R}^{2}=0.9983$ & $\mathrm{~m}_{\mathrm{AT} / \mathrm{ab} .}=5 \mathrm{~m}=19.92$ \\
\hline Aleppo-SYRIA & 40 & $y=4.576 x+18.39$ & $\mathrm{R}^{2}=0.9987$ & $\mathrm{~m}_{\mathrm{AT} / \mathrm{tab} .}=10 \mathrm{~m}^{\prime}=40.20$ \\
\hline
\end{tabular}

\section{TABLE-4 \\ DETERMINATION OF ATORVASTATIN IN SYRIAN PHARMACEUTICAL PREPARATIONS USING DIFFERENTIAL PULSE POLAROGRAPHIC ANALYSISON DROPPING MERCURY ELECTRODE WITH NEGATIVE AMPLITUDE IN BORAX BUFFER AT $\mathrm{pH} 7.5$}

\begin{tabular}{|c|c|c|c|c|}
\hline Commercial name & Contents (mg/tab) & $* \overline{\mathrm{x}},(\mathrm{mg} / \mathrm{tab})$ & $\operatorname{RSD}(\%)$ & Recovery $(\%)$ \\
\hline Atorvex, ctd. tab., Asia & 10 & 10.22 & 3.6 & 102.2 \\
\hline Pharmaceutical Industries & 20 & 20.84 & 3.5 & 104.2 \\
\hline Aleppo-SYRIA & 40 & 40.80 & 3.4 & 102.0 \\
\hline Atorvatin, ctd. tab., Alpha & 10 & 9.88 & 3.7 & 98.8 \\
\hline Aleppo Pharmaceutical Industries, & 20 & 20.14 & 3.6 & 100.7 \\
\hline Aleppo-SYRIA & 40 & 40.00 & 3.4 & 100.0 \\
\hline Lipito-med, Ctd. tab. & 10 & 9.96 & 3.7 & 99.6 \\
\hline Medico Labs. & 20 & 20.60 & 3.5 & 103.0 \\
\hline Homs-SYRIA & 40 & 40.20 & 3.4 & 100.5 \\
\hline Liostatin, ctd. tab. Ibn Al & 10 & 10.31 & 3.6 & 103.1 \\
\hline Haytham, Pharma Industries Co. & 20 & 20.34 & 3.5 & 101.7 \\
\hline Aleppo-SYRIA & 40 & 40.44 & 3.4 & 101.1 \\
\hline Atoraz, Ctd. tab. Razi & 10 & 9.72 & 3.8 & 97.2 \\
\hline pharmaceutical industries & 20 & 19.92 & 3.6 & 99.6 \\
\hline Aleppo-SYRIA & 40 & 40.20 & 3.5 & 100.5 \\
\hline
\end{tabular}

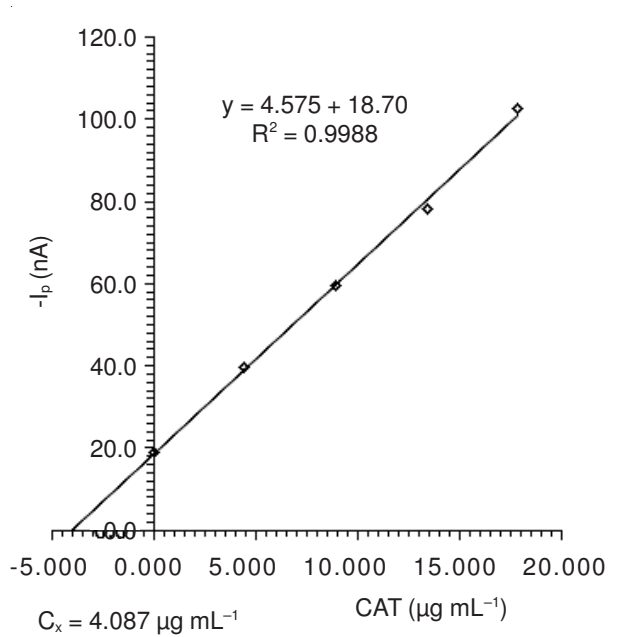

Fig. 6. Standard addition curve for determination of atorvastatin in atorvex $(10 \mathrm{mg} / \mathrm{tab}$.) using differential pulse polarographic analysis on dropping mercury electrode with negative amplitude in borax buffer at $\mathrm{pH} 7.5$ (m) of atorvastatin in one tablet by $\mathrm{mg} / \mathrm{tab}\left(\mathrm{m}_{\mathrm{AT}} / \mathrm{tab}\right.$.) calculated from the following relationship: $m=h . m^{\prime}$, where: $m^{\prime}$ is the amount of atorvastatin in tablet, which calculated from the standard additions curve according to the following regression equation: $\mathrm{y}=\mathrm{a} \cdot \mathrm{x}+\mathrm{b}$; when $\mathrm{y}=0 ; \mathrm{m}^{\prime}=\mathrm{x}=\mathrm{b} / \mathrm{a}=$ intercept/ slope $\left(\mu \mathrm{g} \mathrm{mL}^{-1}\right)$ and $\mathrm{h}$ conversion factor is equal to $2.5,5.0$ and 10 for all pharmaceuticals content 10,20 and $40 \mathrm{mg} / \mathrm{tab}$, respectively.The results of quantitative analysis for atorvastatin in the pharmaceutical preparations using this method were included in Table-4. The proposed method was simple, economic, accurate and successfully applied to the determination of atorvastatin in pharmaceuticals. The results obtained agree well with the contents stated on the labels.

\section{Conclusion}

New, simple and rapid differential pulse polarographic analysis on dropping mercury electrode with negative amplitude in borax buffer at $\mathrm{pH} 7.5$ was developed for determination of atorvastatin in pure form and in pharmaceutical formulations. 
One reduction peak was observed in the range -1310 to -1340 $\mathrm{mV}\left(\mathrm{E}_{\mathrm{p}}\right)$. The peak current $\mathrm{I}_{\mathrm{p}}$ is linear over the ranges 2.00 $60.00 \mu \mathrm{M}$. The relative standard deviation did not exceed $3.8 \%$ for the concentrations of atorvastatin $1.117 \mu \mathrm{g} \mathrm{mL} \mathrm{m}^{-1}$. Regression analysis showed a good correlation coefficient $\left(\mathrm{R}^{2}=0.9994\right)$ between $\mathrm{I}_{\mathrm{p}}$ and concentration over the range of 1.117-33.52 $\mu \mathrm{g} \mathrm{mL}{ }^{-1}$. The LOD and the LOQ were to be $0.129 \mu \mathrm{g} \mathrm{mL}^{-1}$ and $0.390 \mu \mathrm{g} \mathrm{mL}^{-1}$, respectively. The proposed method was successfully applied to the analysis of atorvastatin in pure and pharmaceutical dosage forms with average recovery of 97.2 to $104.2 \%$. The results obtained agree well with the contents stated on the labels.

\section{REFERENCES}

1. S. Reents and J. Seymour, Clinical Pharmacology; An Electronic Reference and Teaching Guide CD-ROM, Gold Standard Multi-media Inc., Tampa, FL (1998).

2. M.K.M.S. El-Din, M.M.F. Salama, W.I. Mohamed-Nassar, A.M.K. Attia and M.Y.M. Kaddah, J. Pharm. Anal., 2, 200 (2012).

3. M. Malinowski, Am. J. Health Syst. Pharm., 55, 2253 (1998).

4. H.S. Malhotra and K.L. Goa, Drugs, 61, 1835 (2001).

5. N.K. Vipul and M. Rajshree, Anal. Sci., 23, 445 (2007).

6. H.W. Darwish, S.A. Hassan, M.Y. Salem and B.A. El-Zeiny, Spectrochim. Acta A, 83, 140 (2011)
7. H.M. Maher, R.M. Youssef, E.M. Hassan, E.I. El-Kimary and M.A. Barary, Drug Test. Anal., 3, 97 (2011).

8. S. Ashour, M. Bahbouh and M. Khateeb, Spectrochim. Acta A, 78, 913 (2011).

9. Y. Kiya, S. Miura, B. Zhang, H. Urata and K. Saku, Endocrinol. J., 53, 865 (2006).

10. E. Guihen, G.D. Sisk, N.M. Scully and J.D. Glennon, Electrophoresis, 27, 2338 (2006).

11. D. Guillen, F. Cofan, E. Ros, O. Millan, M. Cofan, A. Rimola and M. Brunet, Anal. Bioanal. Chem., 394, 1687 (2009).

12. G. Bahrami, B. Mohammadi, S. Mirzaeei and A. Kiani, J. Chromatogr. B, 826, 41 (2005).

13. Y. Shah, Z. Iqbal, L. Ahmad, A. Khan, M.I. Khan, S. Nazir and F. Nasir, J. Chromatogr. B, 879, 557 (2011).

14. R.K. Seshadri, M.M. Desai, T.V. Raghavaraju, D. Krishnan, D.V. Rao and I. E. Chakravarthy, Sci. Pharm., 78, 821 (2010).

15. H. Farahani, P. Norouzi, A. Beheshti, H.R. Sobhi, R. Dinarvand and M.R. Ganjali, Talanta, 80, 1001 (2009).

16. L. Novakova, H. Vlckova, D. Satinsky. P. Sadílek, D. Solichová, M. Bláha, V. Bláha and P. Solich, J. Chromatogr. B, 877, 2093 (2009).

17. M.A. Korany, I.I. Hewala and K.M. Abdel-Hay, J. AOAC Int., 91, 1051 (2008).

18. N. Erk, Crit. Rev. Anal. Chem., 34, 1 (2004).

19. B. Dogan-Topal, B. Uslu and S.A. Ozkan,, Comb. Chem. High Throughput Screen, 10, 571 (2007).

20. B. Dogan-Topal, B. Bozal, B. Demircigil, B. Uslu and S. Ozkan, Electroanalysis, 21, 2427 (2009).

21. E. Dilek, D. Zehra and K. Esma, Coll. Czech. Chem. Commun., 76, 1633 (2011). 